\title{
Techno Economic Analysis of Biomass to Methanol Plant Based on Gasification of Palm Empty Fruit Bunch
}

\author{
Rudy Heryadi ${ }^{1, *}$ and Syukri Muhammad Nur ${ }^{2}$ \\ ${ }^{1}$ Department of Mechanical Engineering, Bina Tunggal Technology College, Jl. H. Wahab Affan I, \\ Bekasi 17134, West Java, Indonesia \\ ${ }^{2}$ Graduate School of Renewable Energy, Darma Persada University, Jl. Taman Malaka Selatan, \\ Pondok Kelapa, Jakarta 13450, Indonesia
}

\begin{abstract}
Biomass from palm empty fruit bunch (EFB) is considered as potential renewable energy sources to be developed in Indonesia. Palm EFB can be efficiently converted into valuable and useful methanol products through gasification. Research about methanol synthesis from various biomass has been done. However, Little research about methanol production based on palm empty fruit bunch gasification has been found, and no research yet on technoeconomic analysis of methanol plant construction based on palm empty fruit bunch gasification. The purpose of this research is to find early-stage feasibility of small-scale methanol plant model based on gasification of palm EFB. Method methanol plant design, investment cost estimation, operating cost estimation, and calculation to estimate profitability in terms of economic feasibility parameters. Economic analysis calculated that the total investment to build a methanol plant in this study was USD 87508479 with manufacturing cost per annum USD 6127 014. Net Present Value (NPV) calculated was USD -51 721064 and IRR at $1.1 \%$. Based on NPV and Internal Rate of Return (IRR) value, the construction of methanol plant is not feasible. Feasibility predicted to be obtained when the capacity of the plant increased fivefold.
\end{abstract}

Keywords: Dimethyl ether, feasibility methanol plant, renewable energy, syngas, waste to energy

\section{Introduction}

The utilization of biomass to be used as one of the energy sources can be done through a gasification process. Gasification is a thermochemical process that converts biomass into a gas called producer gas or synthetic gas (syngas). Syngas is a fuel-based mixture consisting mainly of Hydrogen $\left(\mathrm{H}_{2}\right)$, Carbon Monoxide (CO), and Methane $\left(\mathrm{CH}_{4}\right)$ [1]. Syngas is a raw material for most other chemical products, such as methanol, ammonia, and dimethyl ether (DME). Biomass that has big potential to be utilized is palm EFB waste. In 2015, in Indonesia, the total EFB waste generated was $30.6 \times 10^{6} \mathrm{t} \mathrm{yr}^{-1}$ [2]. Based on Inayat et al. [3], Indonesia is currently the world's largest producer of palm oil resulted in very large EFB. Every kg of Crude Palm Oil (CPO) produced, it will produce $4 \mathrm{~kg}$ of dry biomass.

* Corresponding author : rudy.heryadi@live.com 
About $33 \%$ of biomass is EFB and the rest are palm leaves and stems [4]. Abundant EFB resources have the potential to be used as raw material for further chemical synthesis through the gasification route.

This study, EFB is gasified and further processed to obtain methanol. Methanol has chemical formula $\mathrm{CH}_{3} \mathrm{OH}$ and often abbreviated $\mathrm{MeOH}$. Methanol is toxic, light, colorless, volatile, and flammable liquid with a distinctive odor that like ethanol. Major methanol uses as a fuel. It can be used as a gasoline blendstock, bunker fuel for ships, reactant of biodiesel making reaction, fuel for power generation, and feed for further chemical processes [5].

Research related to the utilization of EFB as a renewable energy source of biomass has been done. Some of these are studies related to the manufacture of biomass pellets to be utilized as feeds of gasifier and boiler reactors by Salomon et al. [6] research related to the utilization of EFB into bio-oil products is conducted by Sukiran et al. [7] which discusses the conversion of EFB to bio-oil through pyrolysis pathway, conversion of EFB into biosyngas by using fluidized bed reactors performed by Mohammed et al. [8], and research by combining pyrolysis catalytic cracking method to produce bio-syngas with gasification by Pradana and Budiman [9]. Some of the research related with the techno-economic analysis of chemical and fuel products based on gasification of EFB was conducted by Do and Lim [10], that was discussed about techno-economic analysis of EFB conversion into bioethanol, and jet-fuel, conversion into power, and fast pyrolysis and bio-oil upgrading, and also research by Do et al. [11] analyze the techno-economic of bio-oil production.

Studies on simulation of gasification process based on biomass gasification to methanol that was discussing methanol production based on gasification of woody biomass in a fluidized bed two stages gasifier, had been done by Clausen [12], and study about technoeconomic analysis of methanol production in existing pulp and paper mill were conducted by Andersson et al. [13]. Other research for methanol synthesis based on gasification were study about simulation of methanol production based on biomass gasification in interconnected beds by Zhang et al. [14], study about modeling cost of methanol production by gasification based on geographical location by Leduc et al. [15], and study about economic and technical analysis of methanol production from residues of palm oil biomass and research done by Gomez et al. [16]. The specific research developed for methanol based on EFB gasification has not yet been found. Therefore, this study arises to provide an economic analysis of methanol production plant based on EFB gasification.

\section{Methodology}

\subsection{Modelling steps undertaken}

The following steps were undertaken to perform the modeling.

i. Collecting information on the existing model of methanol plant that was available.

ii. Performing the simulation by utilizing process engineering simulation tools. In this study, Aspen Hysys was utilized.

iii. Preparing material stream and energy stream to find methanol yield, process efficiency, and energy efficiency.

iv. Equipment sizing through Aspen Hysys Economic Analyzer and manual calculation sizing.

v. Costing and Economic parameters calculation.

Simplified Block Flow Diagram (BFD) of methanol synthesis was developed and shown in Figure 1. The technology and process configuration used for simulation purposes on the model developed was adopting on some research [12-14, 17]. Table 1 summarized 
the methanol plant design step and showed the step of designing methanol plants from the preparation of simulation tools, biomass feedstock, and steam generation, and power generation.

Table 1. The steps of Methanol plant design

\begin{tabular}{|c|c|}
\hline Simulation tools & $\begin{array}{l}\text { The simulation was done by using Aspen Hysys V 8.8. The } \\
\text { input of EFB as a hypothetical solid component was based on } \\
\text { the ultimate analysis of the EFB measured feedstock (daf) } \\
\text { base. From weight percentage of components } \mathrm{C}, \mathrm{H}, \mathrm{O}, \mathrm{N}, \mathrm{S} \text {. }\end{array}$ \\
\hline Biomass feedstock & $\begin{array}{l}\text { The composition of the EFB was based on a dry ash-free base } \\
\text { (daf), and raw composition taken from [18]. The chemical } \\
\text { formula for Aspen hysys hypothetical component was } \mathrm{C}_{4.306} \\
\qquad \mathrm{H}_{6.176} \mathrm{O}_{2.587} \mathrm{~N}_{0.048} \mathrm{~S}_{0.003}\end{array}$ \\
\hline $\begin{array}{l}\text { Biomass pre-treatment to } \\
\text { pellet }\end{array}$ & $\begin{array}{c}\text { The energy required for EFB pellet making is } 210 \mathrm{kWh} / \text { dry } \\
\text { long fiber [5]. It was assumed that dried EFB is the same with } \\
\text { dry long fiber (DLF). }\end{array}$ \\
\hline Gasification & $\begin{array}{l}\text { The process of gasification occurs in Circulating Fluidized } \\
\text { Bed (CFB). Gasification temperature at } 900{ }^{\circ} \mathrm{C} \text { and pressure } \\
\text { at } 10 \text { bar. Detailed of the gasification simulation was based on } \\
\text { earlier work on the simulation of gasification in Circulating } \\
\text { Fluidized Bed gasifier [19]. }\end{array}$ \\
\hline Water gas shift & $\begin{array}{l}\text { WGS reactor adjusted molar ratio } \mathrm{H}_{2} / \mathrm{CO}=2[12] . \\
\text { Temperature }=400^{\circ} \mathrm{C} \text { and pressure }=1000 \mathrm{kPa} \text { based on } \\
\text { [20]. The type of WGS used is High-Temperature WGS } \\
\text { because it favors a greater reaction rate [20]. WGS reactor } \\
\text { volume was obtained by using multiplying volume of reactor } \\
\text { with residence time which is the ideal reactor formula [21], } \\
\text { The residence time value taken was } 1.8 \mathrm{~s} \text { [20]. Catalyst initial } \\
\text { fill is } 60 \% \text { volume of WGS reactor, and the density of } \\
\text { catalyst is } 1600 \mathrm{~kg} \mathrm{~m}^{-3}[20] .\end{array}$ \\
\hline $\begin{array}{l}\text { Water removal and } \\
\text { syngas cleaning }\end{array}$ & $\begin{array}{l}\text { Water removal was modeled using separator as a dryer. and } \\
\text { acid gas was removed by the Rectisol process [22]. After } \\
\text { water removed, syngas entering Acid removal modeled as a } \\
\text { component splitter. } \mathrm{CO}_{2} \text { and } \mathrm{H}_{2} \mathrm{~S} \text { assumed removed at } 90 \% \\
\text { and } 100 \% \text {, respectively [20]. }\end{array}$ \\
\hline Methanol synthesis & $\begin{array}{l}\text { Sweet syngas is compressed into } 5000 \mathrm{kPa}(5 \mathrm{MPa}) \text { [23]. The } \\
\text { reactor used is Gibbs reactor, and reactions involved in } \\
\text { equilibrium [24]. Then, } 79 \% \text { of unconverted is recycled and } \\
21 \% \text { is sent to off-gas for electricity generation [12]. } \\
\text { Catalyst's initial filling quantity was based on Almeland et al. } \\
\text { [25]. To determine catalysts total required in } \mathrm{kg} \text {, the density } \\
\text { of the catalyst is } 1140 \mathrm{~kg} \mathrm{~m}^{-3} \text { [26]. The liquid outlet of Gas- } \\
\text { Liquid separator flows to the purification section. }\end{array}$ \\
\hline $\begin{array}{l}\text { Steam generation and } \\
\text { power generation }\end{array}$ & $\begin{array}{l}\text { Steam generation for the process and power generation was } \\
\text { from the waste heat. Steam generated from waste heat of CFB } \\
\text { gasifier and combination of waste heat from WGS reactor, } \\
\text { Methanol reactor, and a cooler of syngas outlet gasifier. } \\
\text { Power was generated by using one steam turbine system, one } \\
\text { Genset driven by Internal Combustion Engine (ICE) that was } \\
\text { fueled by off-gas, and one genset driven by ICE, fueled by } \\
\text { methanol fuel/product. }\end{array}$ \\
\hline
\end{tabular}




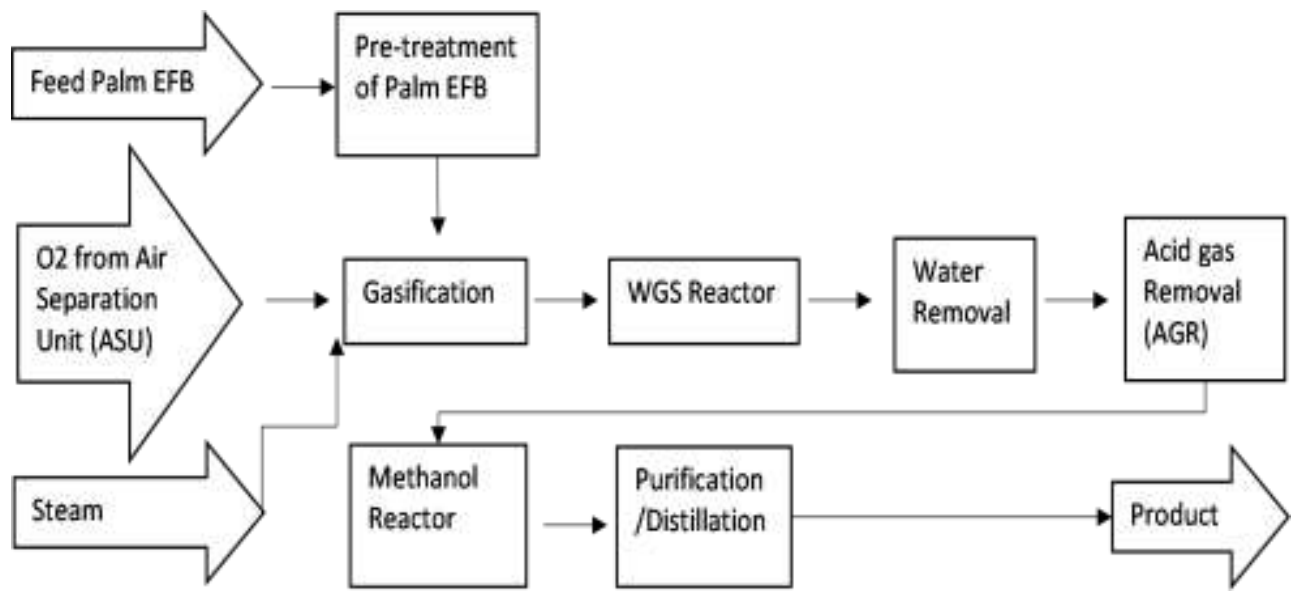

Fig. 1. Simplified BFD of Methanol synthesis based on gasification of palm EFB

\subsection{Economic analysis}

\subsubsection{Market aspect}

It was assumed that the market for methanol is already available, and the location is in one of the palm oil mills that was near to the main road. Location can be selected elsewhere in Indonesia. The price of methanol will follow the amount of Methanex FOB price of Asia Pacific at USD $295 \mathrm{t}^{-1}$ in October 2019 [27].

\subsubsection{Chemical engineering plant cost index}

The investment was a basis to find the chemical engineering plant cost index (CEPCI) that can be calculated by comparing the cost index on the present year to index of reference year [28]. Reference year for main equipment was the year 2014 as a cost basis of Aspen Hysys version 8.8 [29], gasifier and high-pressure feeding system was based on the year 2011 [30], EFB biomass pre-treatment was based on the year 2015 [31], air separation unit was based on year 2007 [32], acid gas removal (Rectisol) was based on year 2007 [32], and the rest of the equipment/section was based on year 2014 [33].

\subsubsection{Rule of six tenth}

Cost for equipment such as gasifier, high pressure (HP) feeding system, air separation unit, and acid gas removal was obtained by using the rule of six-tenths. The basic equation expresses the rule of six-tenths shown by Formula (1) that was obtained from [34].

$$
C_{B}=C_{A}\left(\frac{S_{B}}{S_{A}}\right)^{0.6}
$$

Where, $C_{B}$ is the approximate cost of equipment having to size $S_{B}$ (could be any unit) and $C_{A}$ is the known cost of equipment having size $S_{A}$ (same unit with $S_{B}$ ). 


\subsubsection{Estimation of fix capital cost}

The basic components in the methanol manufacturing plant are the cost of equipment, overhead costs, administrative costs of doing business, and profits. From the list of existing equipment and acceptable raw specifications, estimates can be made. The most important thing is to make a base of the process equipment used from the equipment list. Equipment installation costs can be searched as a percentage of the total equipment cost [28. In this study, the method used to estimate fix capital cost was the percentage method of total plant installation cost [28].

\subsubsection{Estimation of manufacturing cost}

Estimated manufacturing costs covered are as follows: raw material, utility costs, including steam; compressed air, refrigeration, electricity; water treatment or water treatment costs; labor costs; maintenance cost; insurance and taxes; factory overhead costs, all fees on process facilities that cannot be charged into other costs; expenses related to sales and marketing; research and development costs; and administrative costs. This estimation is done by Anderson [35].

\subsubsection{Profit measurement}

Profit is a clear goal, and it is something that can be quantified in an economic evaluation. The measurement by considering the time value of money are:

i. NPV, the value can be obtained from the NPV function of Microsoft excel.

ii. IRR, the value can be obtained from the IRR function of Microsoft Excel.

While for the profitability measurement that is not considering the time value of money is PBP, where PBP can be found by using Formula (2) based on Seider et al. [28].

$$
P B P=\frac{\text { Total Capital Investment }}{\text { Annual Cash Flow Average }}
$$

\section{Results and discussions}

\subsection{Process simulation result}

The process simulation result is presented in Table 2 . The energy efficiency calculation was calculating heat integration on the process to ensure optimal energy utilization.

Table 2. Summary of process simulation result

\begin{tabular}{|c|c|}
\hline Parameter & Value \\
\hline Methanol production rate $\left(\mathrm{t} \mathrm{d}^{-1}\right)$ & 126 \\
\hline Overall thermal efficiency, LHV basis $(\%)$ & 85 \\
\hline Total energy consumption $(\mathrm{kW})$ & 3417 \\
\hline Air Separation Unit $(\mathrm{kW})$ & 1.103 \\
\hline - Syngas Compressor $(\mathrm{kW})$ & 996 \\
\hline - Pre-treatment EFB $(\mathrm{kW})$ & 1.294 \\
\hline - Acid Gas Cleaning $(\mathrm{kW})$ & 11.65 \\
\hline - $\mathrm{CO}_{2}$ Compressor $(\mathrm{kW})$ & 12.35 \\
\hline
\end{tabular}




\subsection{Economic analysis}

The investment for a methanol plant based on EFB gasification was estimated based on the components listed in Table 3. The price of the equipment was obtained from other works by using the six-tenths rule and CEPCI adjustment. It was seen that the gasification equipment purchase was very cost-intensive compares to others. To further analyze the total plant investment, an approach used for the total plant cost was based on delivered-equipment cost for solid-fluid processing plant [28]. The base for production capacity was based on $90 \%$ capacity [28].

Table 3. Summary of plant equipment cost

\begin{tabular}{|c|c|c|c|c|}
\hline Equipment/Section & Ref. Cost $\left(\times 10^{6}\right.$ USD $)$ & Ref. Size & Ref.CEPCI & $\begin{array}{c}\text { Cost year } 2017 \\
\text { CEPCI }=572.8 \\
\times 10^{6} \text { (USD) } \\
\end{array}$ \\
\hline Main Equipment & $\begin{array}{c}2143 \text { (Hysys, cost basis } \\
2014 \text { [29]) }\end{array}$ & & 576.1 & 2.155 \\
\hline Genset Methanol & 0.196 & & & 0.196 \\
\hline Genset Off-gas & 0.5 & & & 0.52 \\
\hline Steam Turbine & $\begin{array}{c}0.338 \text { (Hysys, cost basis } \\
2014 \text { [29]) }\end{array}$ & & 576.1 & 0.336 \\
\hline WGS Reactor & $\begin{array}{c}0.064 \text { (Hysys, cost basis } \\
2014[29])\end{array}$ & & 576.1 & \\
\hline WGS catalyst & $\begin{array}{l}0.027 \text { calculated based on } \\
\text { Florence and Bour [20] }\end{array}$ & & 556.8 & 0.028 \\
\hline Methanol Reactor & $\begin{array}{c}0.0214 \text { (Hysys, cost basis } \\
2014[29] \text { ) }\end{array}$ & & 576.1 & 0.0213 \\
\hline Methanol catalyst & $\begin{array}{l}0.790 \text { calculated based on } \\
\text { Almeland et al. }[25]\end{array}$ & & 576.1 & 0.0785 \\
\hline CFB Gasifier & $28.171[30]$ & 41.7 & 585.7 & 8.750 \\
\hline Air Separation Unit & $82.700[32]$ & 2965 & 525.4 & 16.210 \\
\hline AGR (rectisol) & $28.800[32]$ & 8928 & 525.4 & 5.733 \\
\hline HP Biomass Feed & $24.550[30]$ & 42 & 585.7 & 0.759 \\
\hline
\end{tabular}

The lifetime of the plant was assumed at 30 yr [36]. Purchase equipment cost was marked up at $10 \%$ value to compensate for the delivery since the price quoted usually in the Free on Board (FOB) basis [28]. Total Plant Cost (TPC) as shown in Table 4, based on the delivered-equipment cost of the solid-liquid plant [28] was USD 87508 479. From that total cost, equipment cost was USD 77495 647, and the working capital was USD 10012 832.

Table 4. Methanol plant capital cost

\begin{tabular}{|l|c|c|}
\hline \multicolumn{1}{|c|}{ Component } & Estimation & Cost in USD \\
\hline Main Equipment Cost Plus delivery & $110 \% \mathrm{E}$ & 13350442 \\
\hline Installation & $39 \% \mathrm{E}$ & 5206673 \\
\hline Piping & $31 \% \mathrm{E}$ & 4138637 \\
\hline Electricity & $10 \% \mathrm{E}$ & 1335044 \\
\hline Instrumentation & $26 \% \mathrm{E}$ & 3471115 \\
\hline Yard improvement & $12 \% \mathrm{E}$ & 1602053 \\
\hline
\end{tabular}

(Continued on next pages) 
Table 4. Continued

\begin{tabular}{|l|c|c|}
\hline \multicolumn{1}{|c|}{ Component } & Estimation & Cost in USD \\
\hline Service facilities & $55 \% \mathrm{E}$ & 7342743 \\
\hline Building & $29 \% \mathrm{E}$ & 3871628 \\
\hline Total Direct Cost (DC) & USD 40 318 336 & \\
\hline Engineering and Supervision & $32 \% \mathrm{E}$ & 4272142 \\
\hline contruction expenses & $34 \% \mathrm{E}$ & 4539150 \\
\hline Legal expenses & $4 \% \mathrm{E}$ & 534018 \\
\hline Contractors Fee & $19 \% \mathrm{E}$ & 2536584 \\
\hline Contingency & $37 \% \mathrm{E}$ & 4939664 \\
\hline Total Indirect Cost (IC) & USD 16 821 558 & \\
\hline Total main Plant Cost (TPC) & USD 57 139 894 & \\
\hline $\begin{array}{l}\text { Total Additional Plant equipment } \\
\text { (AGR, ASU, Pre-treatment) }\end{array}$ & USD 20 355 753 & \\
\hline Fix Capital Investment & USD 77 495 647 & \\
\hline Working capital & $11 \%$ TPC & USD 10012832 \\
\hline Total Plant Cost (TPC) & USD 87 508 479 & \\
\hline
\end{tabular}

Manufacturing cost was estimated based on Anderson [35]. The cost of raw material was assumed 0 because EFB used is a waste and obtained from palm oil mill since the location of methanol plant was assumed integrated with palm oil mill. The total operating cost per year as shown in Table 5 is USD 6127014.

Table 5. Methanol plant manufacturing cost

\begin{tabular}{|l|r|l|}
\hline \multicolumn{1}{|c|}{ Cost Component } & Cost (USD) & \multicolumn{1}{c|}{ Remark(s) } \\
\hline Operating Labor cost & 158571 & $\begin{array}{l}\text { Estimation based on average labor } \\
\text { cost in Jakarta, Indonesia. }\end{array}$ \\
\hline Non Operating Labor cost & 95143 & $60 \%$ of Operating labor cost \\
\hline Supplies & 47571 & $30 \%$ of Operating labor cost \\
\hline Administration and overhead & 142714 & $90 \%$ of operating and labor cost \\
\hline Maintenance & 1549913 & $2 \%$ of fix capital investment \\
\hline Raw Material & 0 & EFB waste \\
\hline $\begin{array}{l}\text { Utilities (Water, refrigeration, } \\
\text { water treatment) }\end{array}$ & 774956 & $1 \%$ of fix capital investment \\
\hline Miscelleneous & 774956 & $1 \%$ of fix capital investment \\
\hline & 2583188 & $\begin{array}{l}\text { Straight line depreciation of Total } \\
\text { Direct Cost for 30 yr }\end{array}$ \\
\hline Depreciation & USD 6 127 014 & \\
\hline Total Manufacturing Cost & &
\end{tabular}

A feasibility analysis was conducted to know the profitability of this methanol plant project. The discount rate used assumed the same as the corporate loan interest rate in Indonesia at $10.25 \%$ [37]. Parameters to analyze the profitability of this Methanol plant were calculated and shown in Table 6 .

From Table 6, it was shown for the capacity at $6.16 \mathrm{t} \mathrm{h}^{-1}$ EFB feed, the project was not feasible. Small scale DME plant based on EFB gasification attached to main palm oil mill is not feasible by the current interest rate at $10.25 \%$. To make a project feasible, the option for higher production capacity should be considered for further feasibility study. 
The initial prediction of the feasible capacity of DME plant at $10.25 \%$ discount rate can be done by using sixth-tenths rule for investment cost, and percentage of investment cost for operating cost. At the current study annual operating cost was $5.52 \%$ of total plant cost, this value was assumed constant for $30 \mathrm{yr}$ plant lifetime, and revenue from sales assumed increased linearly according to production capacity. Annual operating cost in percentage was used for scale-up feasibility calculation.

Table 6. Feasibility parameters

\begin{tabular}{lcc}
\hline Feasibility Parameters & Unit & Value \\
\hline NPV & USD & -51721064 \\
IRR & $\%$ & $1.1 \%$ \\
PBP & Years & $>30$ \\
\hline
\end{tabular}

Based on Figure 2, feasibility can be achieved at $30.8 \mathrm{t} \mathrm{h}^{-1}$ EFB biomass input or fivefold from $6.16 \mathrm{t} \mathrm{h}^{-1}$ palm EFB biomass input. This feasibility needs to be analyzed and studied further, including sensitivity analysis to see the impact of changes that can affect the feasibility of the project.

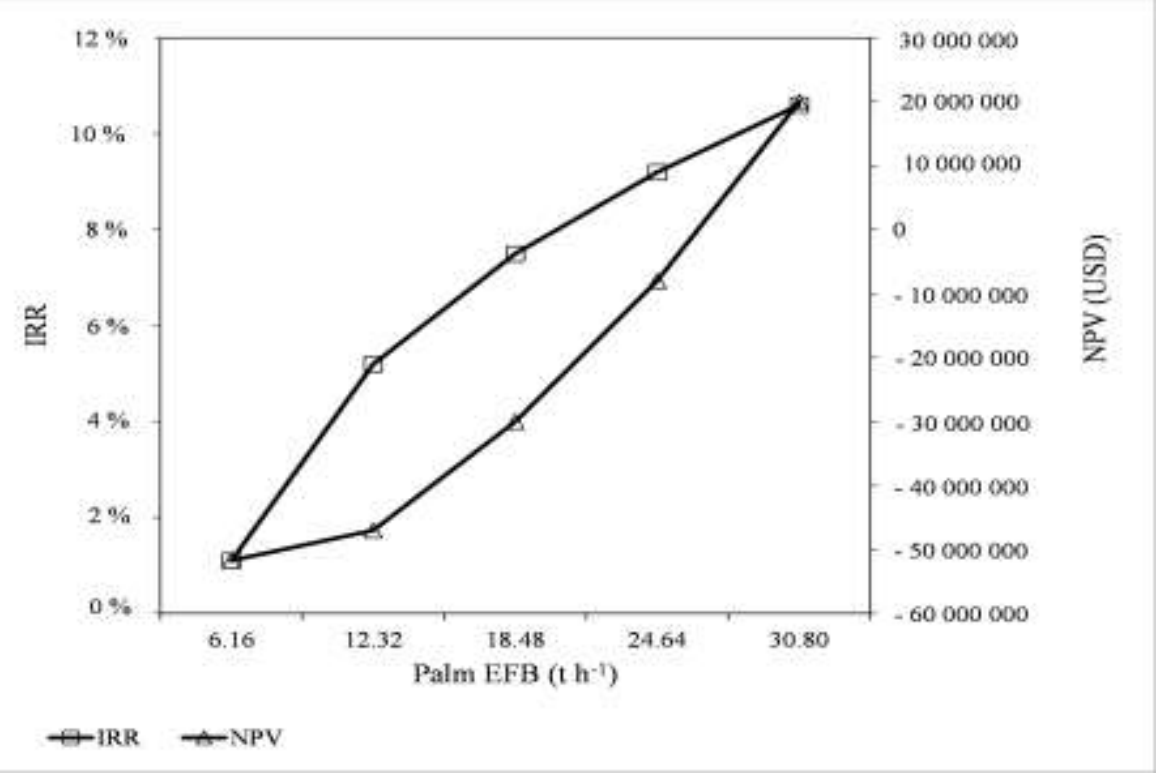

Fig. 2. Prediction of methanol plant feasibility for increased capacity

\section{Conclusion}

This paper exhibits the mass and energy balance and economic aspect of the proposed methanol plant based on gasification of EFB and the model of a methanol plant was designed and simulated by using Aspen Hysys. Total energy consumption was $3417 \mathrm{~kW}$ and the performance of the methanol plant shown by energy efficiency at $85 \%$.

Based on economic analysis, methanol plant at $6.16 \mathrm{t} \mathrm{h}^{-1}$ EFB Feed was not feasible to be built at $10.25 \%$ discount rate, to make project feasible discount rate must be below $1.1 \%$, option for higher production capacity should be considered for a further feasibility study. Initial predictions for feasibility based on production capacity have been made and it was found that a fivefold increase in capacity makes the project feasible. 


\section{References}

1. P. Basu, Biomass gasification and pyrolysis: practical design and theory, Academic press, 2010.

https://www.elsevier.com/books/biomass-gasification-and-pyrolysis/basu/978-0-12374988-8

2. E. Hambali, M. Rivai, IOP Conference Series: Earth and Environmental Science 65, 012050(2017) http://iopscience.iop.org/article/10.1088/1755-1315/65/1/012050

3. A. Inayat, C. Ghenai, M. Naqvi, M. Ammar, M. Ayoub, M. Hussin, Energy Procedia, 105:1242-1249(2017). https://www.sciencedirect.com/science/article/pii/S1876610217304721

4. M. Maitah, P. Prochazka, A. Pachmann, K. Šrédl, H. Řezbová, International Journal of Energy Economics and Policy. 6:35-38(2016). https://www.econjournals.com/index.php/ijeep/article/view/1501

5. R. Heryadi, A. Uyun, E. Yandri, S. Nur, K. Abdullah, O. Anne, IOP Conference Series: Earth and Environmental Science. 293, 012036(2019). https://iopscience.iop.org/issue/1755-1315/293/1

6. M. Salomon, M. F. Gómez, C. Erlich, A. Martin, Biomass Convers. Biorefin., 3:213-229(2013). https://link.springer.com/article/10.1007/s13399-013-0075-5

7. M. A. Sukiran, N. K. A. Bakar, C. M. Chin, J. Oil Palm Res., 21:653-658(2009). http://palmoilis.mpob.gov.my/publications/joprv21dec09-azri.pdf

8. M. Mohammed, A. Salmiaton, W. W. Azlina, M. M. Amran, Bioresour. Technol, 110:628-636(2012). https://www.sciencedirect.com/science/article/pii/S0960852412000624

9. Y. S. Pradana, A. Budiman, Eng. Sci. Technol. an Int. J., 10:1-8(2015). https://repository.ugm.ac.id/id/eprint/138936/contents

10. T. X. Do, Y.-i. Lim, Renewable Energy, 90:307-318(2016). https://www.sciencedirect.com/science/article/abs/pii/S0960148116300301

11. T. X. Do, Y.-i. Lim, H. Yeo, Energ. Conver. Manage., 80:525-534 (2014). https://www.sciencedirect.com/science/article/pii/S0196890414000685

12. L. R. Clausen, Design of novel DME/methanol synthesis plants based on gasification of biomass,[Thesis Phd], Technical University of Denmark, (2011).p.295

http://orbit.dtu.dk/files/6321613/Phd\%20afhandling\%20\%20Lasse \%20R\%20Clausen.pdf

13. J. Andersson, J. Lundgren, M. Marklund, Biomass Bioenergy, 64:256-268 (2014). https://doi.org/10.1016/j.biombioe.2014.03.063

14. Y. Zhang, J. Xiao, L. Shen, Ind. Eng. Chem. Res. 48:5351-5359(2009). https://doi.org/10.1021/ie801983z

15. S. Leduc, E. Schmid, M. Obersteiner, K. Riahi, Biomass Bioenergy, 33:745751(2009). https://doi.org/10.1016/j.biombioe.2008.12.008

16. R. Gomez, L. Corredor, A. Avila, J. Mendoza, A. Bula, Proceedings Paper: Energy Sustainability. 1175-1182(2011) $\underline{\text { http://proceedings.asmedigitalcollection.asme.org/proceeding.aspx? } \text { articleid }=16366}$ $\underline{84}$ 
17. P.-C. Chen, H.-M. Chiu, Y.-P. Chyou, C.-S. Yu, World Acad. Sci. Eng. Technol., 41:989-996 (2010).

http://citeseerx.ist.psu.edu/viewdoc/download?doi=10.1.1.294.1465\&rep=rep1\&typ $\underline{\mathrm{e}=\mathrm{pdf}}$

18. A. Wijono, PLTU Biomasa tandan kosong kelapa sawit studi kelayakan dan dampak lingkungan [PLTU oil palm empty bunch biomass feasibility studies and environmental influences]. Simposium Nasional RAPI XIII 2014, Surakarta.FT UMS.111-18(2014). [in Bahasa Indonesia]

https://www.google.com/url? $\mathrm{sa}=\mathrm{t} \& \mathrm{rct}=\mathrm{j} \& \mathrm{q}=\& \mathrm{esrc}=\mathrm{s} \&$ source $=$ web $\& \mathrm{~cd}=\& \mathrm{cad}=\mathrm{rja} \&$ uact $=8 \&$ ved=2ahUKEwjD6OWi18rrAhX71EsFHTodDBUQFjAAegQIBBAB\&url= https\%3A\%2F\%2Fpublikasiilmiah.ums.ac.id\%2Fbitstream\%2Fhandle $\% 2 \mathrm{~F} 11617 \% 2$ F5492\%2F17.Agung\%2520Wijono.pdf\%3Bsequence\%3D1\&usg=AOvVaw0yyzeG FzAGXHshMgiJylvB

19. R. Heryadi, A. S. Uyun, E. Yandri, S. M. Nur, K. Abdullah, E3S Web of Conferences. 67,02043:1-10(2018)

https://www.e3s-conferences.org/articles/e3sconf/pdf/2018/42/e3sconf_itrec2018_02043.pdf

20. H. Florence, A. Bour, Norway: NTNU, (2016). https://daim.idi.ntnu.no/masteroppgaver/015/15871/masteroppgave.pdf

21. Ideal Reactor Design Equations and Formulas Calculator [Online] Available from https://www.ajdesigner.com/phpreactor/reactor_equations_mean_residence_time.ph p. [Accessed on 27 July 2019]

22. Lurgi, Air Liquide, 1-12(2011). https://www.engineering-airliquide.com/sites/activity eandc/files/2017/11/22/airliquide-ec-technology-handbook-2017.pdf

23. J. Ott, V. Gronemann, F. Pontzen, E. Fiedler, G. Grossmann, D. B. Kersebohm, G. Weiss and C. Witte, Ullmann's Encyclopedia of Industrial Chemistry 6th edition, (2011). https://onlinelibrary.wiley.com/doi/10.1002/14356007.a16_465.pub3

24. K. S. Ng, J. Sadhukhan, Biomass Bioenergy, 35, 115-169, (2011). https://doi.org/10.1016/j.biombioe.2010.12.003

25. S. K. Almeland, K. Meland, D. G. Edvardsen, S. Skogestad, M. Panahi, Norway: Norwegian University of Science and Technology, Department of Chemical Engineering, (2009)

http://folk.ntnu.no/skoge/diplom/prosjekt09/methanolproject/FINAL\%20DOCUMENT.doc

26. F. Samimi, M. R. Rahimpour, A. Shariati, Catalysts, 7,11:332(2017). https://doi.org/10.3390/catal7110332

27. Methanex Monthly Average Regional Posted Contract Price History [Online] Available From https://www.methanex.com/our-business/pricing. [Accessed on 1 October 2019]

28. W. G. Seider, J. D. Seader, D. R. Lewin, S. Widagdo, Product and Process Design Principles : Synthesis, Analysis, and Evaluation 3rd Edition, John Wiley \& Sons Inc., 2009 https://www.academia.edu/16568227/208468464-Product-and-Process-DesignPrinciples-Synthesis-Analysis-and-Design-Third-Edition_1_

29. O. J. Symister, Florida: Florida Institute of Technology (2016). https://pdfs.semanticscholar.org/9e18/9b6e79fb68f4ee8b341497301051ada0ea36.pd $\underline{f}$

30. M. Worley, J. Yale, Biomass gasification technology assessment: Consolidated report, National Renewable Energy Lab.(NREL), Golden, CO (United States), 2012 
https://www.nrel.gov/docs/fy13osti/57085.pdf

31. GEMCO Pellet Plant in Malaysia / Malaysian Oil Palm Biomass Study [Online] Available from http://www.biomass-energy.org/blog/efb-pellet-plant-inmalaysia.html. [Accessed on 25 July 2019]

32. K. M. Holmgren, IVL Swedish Envrionmental Research Institute, (2015). https://www.ivl.se/download/18.7e136029152c7d48c202a1d/1465298345076/B222 $\underline{1 . p d f}$

33. Matches' Process Equipment Cost Estimates [Online] Available from http://matche.com/equipcost/Default.html. [Accessed on 25 July 2019]

34. R. Smith, Chemical Process: Design and Integration, John Wiley \& Sons, 2005 https://imtk.ui.ac.id/wp-content/uploads/2014/02/Chemical-Process-Design-andIntegration.pdf

35. J. Anderson, Cep, 27-31, (2009) http://www.janecki.pr.radom.pl/394/CostEstn.pdf

36. E. C. Tan, M. Talmadge, A. Dutta, J. Hensley, J. Schaidle, M. Biddy, D. Humbird, et al., Process Design and Economics for the Conversion of Lignocellulosic Biomass to Hydrocarbons via Indirect Liquefaction. Thermochemical Research Pathway to High-Octane Gasoline Blendstock Through Methanol/Dimethyl Ether Intermediates, National Renewable Energy Lab.(NREL), Golden, CO (United States), 2015 https://www.nrel.gov/docs/fy15osti/62402.pdf

37. Danamon Prime Lending Rate [Online] Available from https://www.danamon.co.id/en/Tentang-Danamon/SBDK. [Accessed on 31 July 2020] 